\title{
Low maize pollen collection and low pesticide risk to honey bees in heterogeneous agricultural landscapes
}

\author{
Christine Urbanowicz ${ }^{1,2}$, Nicolas BAert ${ }^{1}$, Sarah E. Bluher ${ }^{1}$, Katalin BörÖCZKY ${ }^{1}$, \\ Marcel RAmos ${ }^{1}$, Scott H. McArT ${ }^{1}$ \\ ${ }^{1}$ Department of Entomology, Cornell University, Ithaca, NY, USA \\ ${ }^{2}$ Comstock Hall, Cornell University, Ithaca, NY, USA
}

Received 6 December 2018 - Revised 12 April 2019 - Accepted 26 April 2019

\begin{abstract}
Honey bees foraging on and around maize may be exposed to a number of pesticides, including neonicotinoids, but this exposure has not been well quantified in heterogeneous landscapes. Such landscapes may provide alternative foraging resources that add to or buffer pesticide risk. We assessed the influence of landscape context and maize pollen collection on pesticide levels during maize flowering. We quantified pesticides in (1) bee bread from 49 hives across New York and (2) pollen trapped weekly in one yard. Landscape composition and percent maize pollen were not related to pesticide levels. Furthermore, pesticide risk was low $\left(<1 \%\right.$ contact $\left.\mathrm{LD}_{50}\right)$ in all but one of the pollen samples, and maize pollen was absent in the majority of samples. Our results suggest that hives near maize fields during maize flowering are not necessarily exposed to high levels of neonicotinoids and other pesticides in pollen, especially if uncontaminated pollen sources exist nearby.
\end{abstract}

maize / Zea mays / corn / pesticides / neonicotinoids / pollinator / Apis mellifera

\section{INTRODUCTION}

Pesticides have been implicated as a major cause of bee declines (Potts et al. 2010; Goulson et al. 2015). Lab and field studies show that fieldrelevant pesticide exposure can affect honey bee queen production, colony size, worker development and mortality, and susceptibility to parasites and pathogens (Wu et al. 2011, 2012; Prisco et al. 2013; Tsvetkov et al. 2017). Of particular concern is the risk posed by mass-flowering crops, such as maize and soybeans, due to the volume and types of pesticides applied, the method of application, and the high abundance of pollen and nectar available to bees (Cresswell 2011; Rundlöf et al. 2015). Few studies have investigated how pesti-

Corresponding author: C. Urbanowicz, cmu22@cornell.edu

Handling Editor: Monique Gauthier cide risk from mass-flowering crops varies across landscapes and throughout the growing season; this information could help predict where and when bees are most likely to encounter high-risk pesticide exposure (Park et al. 2015; Woodcock et al. 2017).

As the crop covering the most land area in the USA, more pesticides by weight are applied to maize (corn, Zea mays L.) than any other crop in the country (Fernandez-Cornejo et al. 2014). Bees foraging in and around maize fields face multiple routes of pesticide exposure (Krupke et al. 2012). Similar to other mass-flowering field crops, the vast majority of maize seed is coated with neonicotinoids, with national estimates ranging from 75 to $100 \%$ of maize acres treated in 2011 (Douglas and Tooker 2015). This class of pesticides contains some of the highest risk agrochemicals in terms of toxicity and occurrence in hives (SanchezBayo and Goka 2014). Seed-treatment neonicotinoids first enter the environment during 
sowing, when contaminated dust from treated seeds is released (Krupke et al. 2012). After sowing, bees can be exposed to seed-treatment neonicotinoids via two routes. First, residues can reach bordering crops and wildflowers via leaching into the soil and wind-blown contaminated dust (Krupke et al. 2012; Botías et al. 2015; Smart et al. 2016). Second, because neonicotinoids are systemic insecticides, they are taken up by plant tissues and can be found in all parts of a treated plant, including pollen (Simon-Delso et al. 2015). Residues in maize pollen can reach average concentrations of $2.1 \mathrm{ppb}$ imidacloprid (Bonmatin et al. 2005) and $3.9 \mathrm{ppb}$ clothianidin (Krupke et al. 2012). Although these concentrations are low relative to the honey bee contact $\mathrm{LD}_{50}$ of $440 \mathrm{ppb}$ of both pesticides (McArt et al. 2017), there is potential of risk because maize produces a large quantity of pollen that can be a dominant late-summer foraging resource (Keller et al. 2005; Odoux et al. 2012). Furthermore, chronic exposure to neonicotinoid concentrations less than $5 \mathrm{ppb}$ can have sublethal effects on honey bee performance (Sandrock et al. 2014; Williams et al. 2015).

Bees foraging on maize and non-target wildflowers in field margins may also be exposed to a number of other fungicides, herbicides, and insecticides contained within the seed treatment or sprayed on maize fields (Fernandez-Cornejo et al. 2014; Long and Krupke 2016). These other pesticides may exhibit high toxicity alone or in combination with each other and neonicotinoids, resulting in synergistic effects on bee performance (Gill et al. 2012; Sanchez-Bayo and Goka 2014; Tsvetkov et al. 2017; Sgolastra et al. 2018).

Despite these multiple potential routes of pesticide exposure, bees may be able to avoid pesticide risk if there are adequate alternative foraging resources. For example, Park et al. (2015) found that pesticide-related declines in wild bee abundance were buffered by the availability of natural areas in an agricultural landscape, potentially because these areas provided non-contaminated wildflowers. Honey bees may also benefit from natural areas, and colonies surrounded by natural areas have been shown to have less pesticide residue in their bee bread than colonies near agricultural areas (Lawrence et al. 2016). Furthermore, honey bees have been shown to extend their foraging range to collect non-maize pollen, suggesting that they prefer to forage on alternative resources when available (Danner et al. 2014). At the same time, bees may also forage on other crops that can contribute to pesticide residues in bee-collected pollen, and the area of these crops may be an important determinant of pesticide risk (McArt et al. 2017). Given the potential for the surrounding landscape to influence pesticide exposure, it is important to incorporate information on landscape context into risk models.

We evaluated the contribution of maize to pesticide exposure and risk to honey bees (Apis mellifera) during and after the maize flowering period in New York. Thirty percent of cropland in New York is planted in maize (USDA-NASS 2014), and beekeepers in this state have expressed concern that the health of their colonies may be related to pesticide applications on this crop. We predicted that exposure (measured as total pesticide concentration) and risk (a function of pesticide concentration and toxicity) in bee-collected pollen would be highest in landscapes dominated by maize fields and other crops. Moreover, because pesticides may enter the bees' diet via directly foraging on maize pollen, we predicted that exposure and risk would be positively associated with the proportion of maize pollen grains in beecollected pollen. We used a two-prong approach to test these predictions. In 2015, we sampled bee bread from hives across western New York during the maize flowering period, and we related pesticide residues to landscape context and percent maize pollen collected. In 2016, we sampled bee-collected pollen in one location once per week during and after the maize flowering period, and we tested whether pesticide exposure and risk covaried with percent maize pollen collected.

\section{METHODS}

\subsection{Pollen sampling}

During the maize flowering period in 2015 (late July to mid-August), we sampled 49 hives within separate bee yards managed by 13 beekeepers across western New York (Figure 1). We contacted beekeepers throughout this period and timed our visits for when beekeepers observed maize flowering in fields near each yard. All bee 


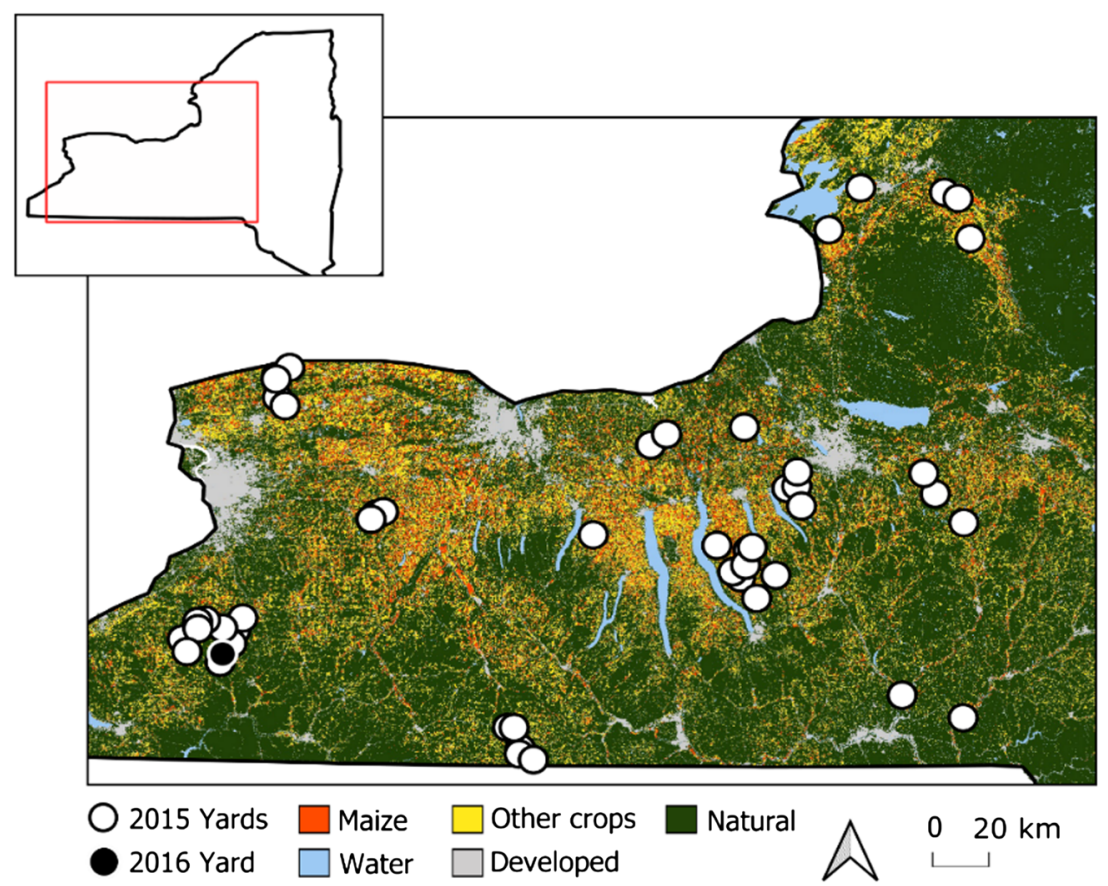

Figure 1. Study area in western New York with locations of honey bee yards where pollen was sampled in 2015 (white circles) and 2016 (black circle).

yards were within $400 \mathrm{~m}$ of maize fields, with a median distance of $67 \mathrm{~m}$. From one haphazardly selected hive in each yard, we collected approximately 4 to $6 \mathrm{~g}$ of fresh bee bread, representing $70-100$ cells, which is the typical mass of pollen used for pesticide residue analyses (Mullin et al. 2010; Pettis et al. 2013; McArt et al. 2017). Fresh bee bread appeared chalky, light in color, and loosely compacted (Klungness and Peng 1983; Tsvetkov et al. 2017), and it was easily distinguished from older, glossier bee bread. Because $\sim 80 \%$ of bee bread is consumed within 4 days of pollen collection (Anderson et al. 2014), our samples integrate several days of foraging. Furthermore, two studies have documented that pesticides dominant in pollen loads were also dominant in fresh bee bread (Frazier et al. 2008; Manning 2018), suggesting that bee bread residues reflect recent exposure. Bee bread samples were immediately placed on dry ice and stored in $\mathrm{a}-80{ }^{\circ} \mathrm{C}$ freezer until lab analysis.

In 2016 (late July to mid-September), we used pollen traps to collect pollen from four hives in one yard that was $340 \mathrm{~m}$ from maize. Pollen was collected once weekly for 8 weeks, with approximately half of the samples taken during maize flowering and half after maize flowering. During each sampling period, between $\sim 200$ and $500 \mathrm{~g}$ of pollen was collected for 1 to 2 days via a 10-frame drawer pollen trap (Mann Lake, Hackensack, $\mathrm{MN})$. The pollen was then mailed to the lab with ice packs and stored in $\mathrm{a}-80{ }^{\circ} \mathrm{C}$ freezer immediately upon receipt. We used pollen traps rather than bee bread for this longitudinal study so that the pollen samples represented snapshots in time rather than pollen collected over potentially overlapping time periods.

\subsection{Maize pollen identification}

We quantified the proportion of maize pollen grains in bee-collected pollen using standard microscopy techniques described in McArt et al. (2017). Briefly, each bee bread sample from 2015 and each pollen trap sample from 2016 was homogenized with a gloved hand for at least $5 \mathrm{~min}$, and a 24-mg subsample was taken. We added $500 \mu \mathrm{l}$ DI water, vortexed for $15 \mathrm{~s}$, 
sonicated for $2 \mathrm{~min}$, and then centrifuged for $3 \mathrm{~min}$ at $16,000 \mathrm{~g}$. Water was removed, $200 \mu \mathrm{l}$ $95 \%$ ethanol was added, and then the sample was vortexed and sonicated as previously. Ten microliters of the resulting suspension was added to a clean glass slide along with $40 \mu \mathrm{l}$ Calberla's solution, mixed, allowed to sit at $25 \mathrm{C}$ for $20 \mathrm{~min}$, covered with a coverslip, and sealed with clear nail polish. At $\times 400$ magnification, a transect was initiated at a random location on each slide, and all pollen grains that were entirely in the field of view were classified as either maize or other until a total of 300 pollen grains was reached.

\subsection{Residue analysis}

For the 2015 samples, we quantified 23 pesticides (13 insecticides, 9 fungicides, 1 herbicide; Table I) from bee bread using a modified QuEChERS extraction protocol (Anastassiades et al. 2003), described in detail in McArt et al. (2017). Briefly, for each bee bread sample, a $3 \pm$ $0.004-g$ subsample was homogenized then processed via two sequential solid phase extraction (SPE) cleanup steps. Following cleanup, samples were analyzed in a triple quadrupole LC-MS/MS system (Accela liquid chromatograph coupled with a TSQ Quantum Access mass spectrometer; Thermo Scientific) equipped with a $\mathrm{C} 18$ reversedphase column (Kinetex 2.6 $\mu \mathrm{m}$ EVO C18, $150 \times$ $2.10 \mathrm{~mm}$; Phenomenex). Analyte concentrations in the final extracts were determined based on the fitted curves, and limits of detection and quantitation were determined based on the lowest working calibration point (see McArt et al. 2017 for details).

For the 2016 samples, we expanded our multiresidue pesticide analysis and quantified 44 pesticides (19 insecticides, 18 fungicides, 4 herbicides, 2 miticides, 1 synergist; Table II) from trapped pollen. For each trapped pollen sample, a $5 \pm$ 0.05 -g subsample was homogenized in $5 \mathrm{~mL}$ of water, $5 \mathrm{~mL}$ of acetonitrile $0.1 \%$ acetic acid (containing the internal standards), and $7.5 \mathrm{~g}$ of AOAC extraction buffer $\left(6 \mathrm{~g}\right.$ anhydrous $\mathrm{MgSO}_{4}+1.5 \mathrm{~g}$ sodium acetate) and then processed via two sequential SPE cleanup steps, as before (McArt et al. 2017). All samples were then analyzed by LC-ESI-MS/MS (Vanquish UHPLC coupled with a TSQ Quantis Mass Spectrometer; Thermo Scientific) equipped with a $\mathrm{C} 18$ reversed-phase column (Accucore aQ $2.6 \mu \mathrm{m}, 100 \times 2.10 \mathrm{~mm}$; Thermo Scientific). Detection parameters were optimized for each analyte by infusing a $1 \mathrm{ng} / \mu \mathrm{l}$ solution in acetonitrile with $0.1 \%$ formic acid into the mobile phase flow. For each analyte, the two most abundant transitions were monitored. The most abundant one was used for quantification, and the other was used for confirmation. Calibration solutions were prepared in an extracted pesticide-free matrix in the range of 0.00001$1 \mathrm{ng} / \mu \mathrm{l}$. Analyte concentrations in the final extracts were determined as before, and limit of quantification was determined based on the signal-to-noise ratio.

Total pesticide concentration per sample was calculated by summing concentrations greater than the limit of quantification. To estimate pesticide risk from residues, we computed a Pollen Hazard Quotient (PHQ; Stoner and Eitzer 2013). We first computed a raw PHQ by dividing each pesticide residue (ng/g pollen) by the respective honey bee contact $\mathrm{LD}_{50}(\mu \mathrm{g} / \mathrm{bee})$, assuming an average adult bee weight of $100 \mathrm{mg}$ and that exposure occurs from contacting a body-weight equivalent of pollen over 2-4 days (Frazier et al. 2015). Toxicity data for honey bees were obtained from the Tomlin Pesticide Manual (Tomlin 2013), the ECOTOX database of the United States Environmental Protection Agency (http://cfpub.epa. gov/ecotox/), and the AgriTox Database of the French government (http://www.agritox.anses. fr/index.php). The PHQ values were summed across pesticides within each sample to assess total risk.

\subsection{Landscape analysis}

We analyzed landscape context using the 30-m resolution Cropland Data Layer (USDA-NASS 2014). We quantified the percent covers of maize fields, other cropland (soybeans, barley, winter wheat, rye, oats, speltz, alfalfa, buckwheat, dry beans, tomatoes, hops, clover, cherries, apples, grapes, Christmas trees, grass, fallow, triticale, plums, squash, pumpkins, cabbage, cauliflower, spring wheat, millet, onion, cucumber, peas, carrots, strawberries, turnips, lettuce, potatoes, 
Table I. Pesticide residues in recently collected bee bread from 49 hives during maize flowering in 2015. LOD limit of detection, $L O Q$ limit of quantification, $P H Q$ pollen hazard quotient, $N N I$ neonicotinoid. Pesticides analyzed but not detected, with LOD and LOQ in parts per billion in parentheses: Atrazine $(36 ; 108)$, Avermectin B1a $(3.6 ; 10.8)$, Boscalid (36; 108), Clothianidin (35.5; 107.7), Fenbuconazole $(35.5 ; 107.7)$, Fenpyroximate $(1.4 ; 4.3)$, Fluxapyroxad (3.6; 10.8), Imidacloprid (3.6; 10.8), Myclobutanil (36; 108), Penthiopyrad (1.4; 4.3), Spinosyn A $(1.4 ; 4.3)$, Thiamethoxam $(3.6 ; 10.8)$

\begin{tabular}{llllllll}
\hline Compound & Type & $\begin{array}{l}\text { Contact } \\
\text { LD }_{50} \\
(\mu \mathrm{g} / \mathrm{bee})\end{array}$ & $\begin{array}{l}\text { Limit of } \\
\text { detection } \\
(\mathrm{ppb})\end{array}$ & $\begin{array}{l}\text { Limit of } \\
\text { quantification } \\
(\mathrm{ppb})\end{array}$ & $\begin{array}{l}\text { Detections } \\
\text { above } \\
\text { LOD }\end{array}$ & $\begin{array}{l}\text { Detections } \\
\text { above } \\
\text { LOQ }\end{array}$ & $\begin{array}{l}\text { Mean } \\
\text { concentration } \\
\text { when above } \\
\text { LOQ (ppb) }\end{array}$ \\
\hline Cyprodinil & Fungicide & 100 & 0.4 & 1.1 & 8 & 7 & 2.32 \\
Trifloxystrobin & Fungicide & 200 & 0.4 & 1.1 & 5 & 2 & 1.66 \\
Acetamiprid & $\begin{array}{l}\text { Insecticide } \\
\text { (NNI) }\end{array}$ & 7.9 & 1.4 & 4.3 & 3 & 1 & 8.22 \\
Thiophanate-Me & Fungicide & 100 & 1.4 & 4.3 & 3 & 1 & 8.04 \\
Carbaryl & Insecticide & 0.84 & 3.6 & 10.8 & 2 & 0 & 0 \\
Phosmet & Insecticide & 0.62 & 355 & 1077 & 1 & 1 & 1173.43 \\
Chlorantraniliprole & Insecticide & 4 & 3.6 & 10.8 & 1 & 0 & 0 \\
Difenoconazole & Fungicide & 101 & 1.4 & 4.3 & 1 & 0 & 0 \\
Indoxacarb & Insecticide & 0.118 & 36 & 108 & 1 & 0 & 0 \\
Spinetoram J & Insecticide & 0.024 & 1.4 & 4.3 & 1 & 0 & 0 \\
Thiacloprid & Insecticide & 37.83 & 3.6 & 10.8 & 1 & 0 & 0 \\
& (NNI) & & & & & & 0 \\
\hline & & & & & & & 0
\end{tabular}

sunflower, and sorghum), and natural or seminatural areas (shrubland, developed open, developed low, deciduous forest, evergreen forest, mixed forest, woody wetlands, and herbaceous wetlands, clover/wildflowers) within $2 \mathrm{~km}$ of each hive, covering the typical foraging distance of honey bees (Visscher and Seeley 1982; SteffanDewenter and Kuhn 2003; Couvillon et al. 2014).

\subsection{Statistical analysis}

For the 2015 dataset, we tested whether pesticide exposure (total concentration in parts per billion; ppb) and risk (PHQ) were related to landscape context and percent maize pollen in bee bread. For each response variable, we used a generalized linear mixed model with the Tweedie compound Poisson distribution, which is appropriate for continuous zero-inflated data (glmmTMB function, "TMB" package, Magnusson et al. 2017). As fixed effects, we included the percent covers of maize fields and other cropland within $2 \mathrm{~km}$ of the hives and percent maize pollen in bee bread. We did not include percent cover of natural areas in the model because of multicollinearity with the percent covers of maize and other cropland. We included beekeeper identity as a random effect because beekeeper apiaries were clustered in space, leading to spatial autocorrelation of pesticide levels, and because management decisions by the beekeeper, such as applying miticides, could influence pesticide concentrations. Significance was assessed using likelihood ratio tests. Because the concentration of a single pesticide, phosmet, in one hive was three orders of magnitude higher than all other detections, we re-ran the models after removing this outlier. All analyses here and below were conducted in R 3.3.1 (R Core Team 2016).

For the 2016 dataset, we used separate linear mixed-effects models to relate total pesticide exposure (ppb) and risk (PHQ) to percent maize in trapped pollen. Pesticide exposure, risk, and percent maize pollen were $\log (x+1)$ transformed. Hive identity (four hives) was included as a fixed effect, and sampling date (eight dates) was included as a random effect to account for temporal 
Table II. Pesticide residues in trapped pollen from bee hives during and after maize flowering in 2016 ( $n=22$ samples total). $L O D$ limit of detection, $L O Q$ limit of quantification, $P H Q$ pollen hazard quotient. Pesticides analyzed but not detected, with LOD and LOQ in parts per billion in parentheses: Avermectin B1a $(0.76 ; 2.51)$, Boscalid (14.29; 47.14), Carbaryl (1.9; 6.29), Chlorpyrifos $(95.24 ; 314.29)$, Clothianidin (15.24; 50.29), Coumaphos (1.9; 6.29), Cyantraniliprole (0.16; 0.53), Difenoconazole (0.48; 1.57), Dithiopyr (20.19; 66.63), Emamectin B1a (0.05; 0.16), Emamectin B1b (0.19; 0.63), Fenbuconazole (1.9; 6.29), Fenpyroximate $(0.19 ; 0.63)$, Fluopyram $(0.48 ; 1.57)$, Fluxapyroxad (1.9; 6.29), Indoxacarb (1.9; 6.29), Metolachlor (0.48; 1.57), Myclobutanil (0.95; 3.14), Penthiopyrad (0.95; 3.14), Phosmet (1.9; 6.29), Prodiamine (19.81; 65.37), Propiconazole (0.58; 1.92), Pyrimethanil $(0.95 ; 3.14)$, Spinetoram J $(0.07 ; 0.24)$, Spinetoram L $(0.02 ; 0.08)$, Spinosyn A $(0.02 ; 0.07)$, Spinosyn D $(0.01 ; 0.05)$, Thiacloprid $(0.3 ; 1.01)$, Thiamethoxam $(1.79 ; 5.91)$, Trifloxystrobin $(0.19 ; 0.63)$

\begin{tabular}{|c|c|c|c|c|c|c|c|}
\hline Compound & Type & $\begin{array}{l}\text { Contact } \\
\mathrm{LD}_{50} \\
(\mu \mathrm{g} / \mathrm{bee})\end{array}$ & $\begin{array}{l}\text { Limit of } \\
\text { detection } \\
(\mathrm{ppb})\end{array}$ & $\begin{array}{l}\text { Limit of } \\
\text { quantification } \\
(\mathrm{ppb})\end{array}$ & $\begin{array}{l}\text { Detections } \\
\text { above } \\
\text { LOD }\end{array}$ & $\begin{array}{l}\text { Detections } \\
\text { above } \\
\text { LOQ }\end{array}$ & $\begin{array}{l}\text { Mean } \\
\text { concentration } \\
\text { when above } \\
\text { LOQ (ppb) }\end{array}$ \\
\hline Piperonyl butoxide & Synergist & 17 & 0.05 & 0.16 & 13 & 8 & 0.39 \\
\hline Azoxystrobin & Fungicide & 200 & 0.05 & 0.16 & 9 & 2 & 0.61 \\
\hline Thiophanate-Me & Fungicide & 100 & 0.05 & 0.16 & 6 & 6 & 0.54 \\
\hline Chlorantraniliprole & Insecticide & 4 & 0.1 & 0.31 & 5 & 2 & 0.59 \\
\hline Amitraz & Miticide & 50 & 0.005 & 0.016 & 4 & 3 & 0.07 \\
\hline Cyflufenamid & Fungicide & 100 & 0.97 & 3.21 & 3 & 1 & 3.39 \\
\hline Pyraclostrobin & Fungicide & 100 & 0.05 & 0.16 & 2 & 1 & 0.51 \\
\hline Acetamiprid & $\begin{array}{l}\text { Insecticide } \\
\text { (NNI) }\end{array}$ & 7.9 & 0.3 & 0.97 & 2 & 0 & 0 \\
\hline Nitenpyram & $\begin{array}{l}\text { Insecticide } \\
\text { (NNI) }\end{array}$ & 0.138 & 2.02 & 6.66 & 1 & 1 & 10.42 \\
\hline Cyprodinil & Fungicide & 100 & 0.48 & 1.57 & 1 & 1 & 4.75 \\
\hline Atrazine & Herbicide & 97 & 0.58 & 1.9 & 1 & 0 & 0 \\
\hline Imidacloprid & $\begin{array}{l}\text { Insecticide } \\
\text { (NNI) }\end{array}$ & 0.044 & 0.69 & 2.26 & 1 & 0 & 0 \\
\hline Penconazole & Fungicide & 12 & 1.9 & 6.29 & 1 & 0 & 0 \\
\hline Propamocarb & Fungicide & 100 & 0.19 & 0.63 & 1 & 0 & 0 \\
\hline
\end{tabular}

autocorrelation (lmer function, "lme4" package, Bates et al. 2018).

\section{RESULTS}

\subsection{5-across landscapes}

The landscape within $2 \mathrm{~km}$ of each bee yard was dominated by either natural land area (median cover $51 \%$, range $24-88 \%$ ) or crops other than maize (median cover $23 \%$, range $4-51 \%$ ). Maize was always present but never a dominant land use (median cover $13 \%$, range $1-36 \%$ ).

In total, we detected 11 pesticides in the bee bread samples collected in 2015 (Table I). Pesticides were detected in $33 \%$ of samples (16 of 49 hives), and the most commonly detected pesticides were two fungicides: cyprodinil and trifloxystrobin. With one exception, total pesticide concentrations and pollen hazard quotients were generally low when pesticides were detected $\left(<2 \mathrm{ppb}\right.$ and $<0.1 \%$ of the contact $\mathrm{LD}_{50}$, respectively). In one hive, phosmet was found at a concentration of $1173 \mathrm{ppb}(18.9 \%$ contact $\mathrm{LD}_{50}$ ). In this hive, bee bread contained $0.34 \%$ maize pollen, and the percent cover of surrounding maize fields was relatively low (6.1\%). Across all hives, bee bread always contained less than $5 \%$ maize pollen, with maize pollen absent in $61 \%$ of samples. There were no detections of the three most commonly used seed-treatment neonicotinoids (imidacloprid, clothianidin, and thiamethoxam, Douglas and Tooker 2015). 
Pesticide exposure, measured as total pesticide concentration (ppb), was not related to landscape context (percent cover maize fields: $\chi^{2}(1)=0.81$; $p=0.37$, Figure $2 \mathrm{a}$; other cropland: $\chi^{2}(1)=$ $0.0092 ; p=0.92$, Figure $2 b)$ or percent maize pollen in bee bread $\left(\chi^{2}(1)=0.46 ; p=0.50\right.$, Figure 2c). Similarly, pesticide risk was not related to landscape context (percent cover maize fields $\chi^{2}(1)=2.78 ; p=0.10$, Figure $2 \mathrm{~d}$; other cropland: $\chi^{2}(1)=0.08 ; p=0.77$, Figure $2 \mathrm{e}$ ) or percent maize pollen in bee bread $\left(\chi^{2}(1)=0.30\right.$; $p=0.58$, Figure $2 \mathrm{f})$. These relationships remained non-significant after removing the outlying phosmet concentration ( $p>0.09$ in all cases).

\subsection{6-across time}

The yard sampled in 2016 had similar land-use values as the median values of the 2015 yards. Natural area was dominant ( $52 \%$ cover), followed by cultivated crops other than maize $(20 \%)$ and maize (12\%). In total, we detected 14 pesticides in 2016 (Table II). The mostly commonly detected pesticides were piperonyl butoxide (synergist), azoxystrobin (fungicide), and thiophanate methyl (fungicide). Pesticides were detected in all of the samples, but the total risk per sample was always less than $1 \%$ of the contact $\mathrm{LD}_{50}$. Of the three most commonly used neonicotinoids for maize seed treatment, there was one detection of imidacloprid and no detections of thiamethoxam or clothianidin. Maize pollen collection varied across time (median $0 \%$, range $0-48 \%$ ), and maize pollen was absent in $59 \%$ of samples (13 of 22 samples).

Neither pesticide exposure (total pesticide concentration) nor pesticide risk (PHQ) was significantly related to the percent maize pollen in trapped pollen $\left(\chi^{2}(1)=0.83 ; p=0.36 ; \chi^{2}(1)=0.63 ; p=\right.$ $0.43)$. Maize pollen collection was highest on the first sampling date (29 July, Figure 3a), while pesticide exposure (Figure 3b) and risk (Figure 3c) peaked in mid-August.
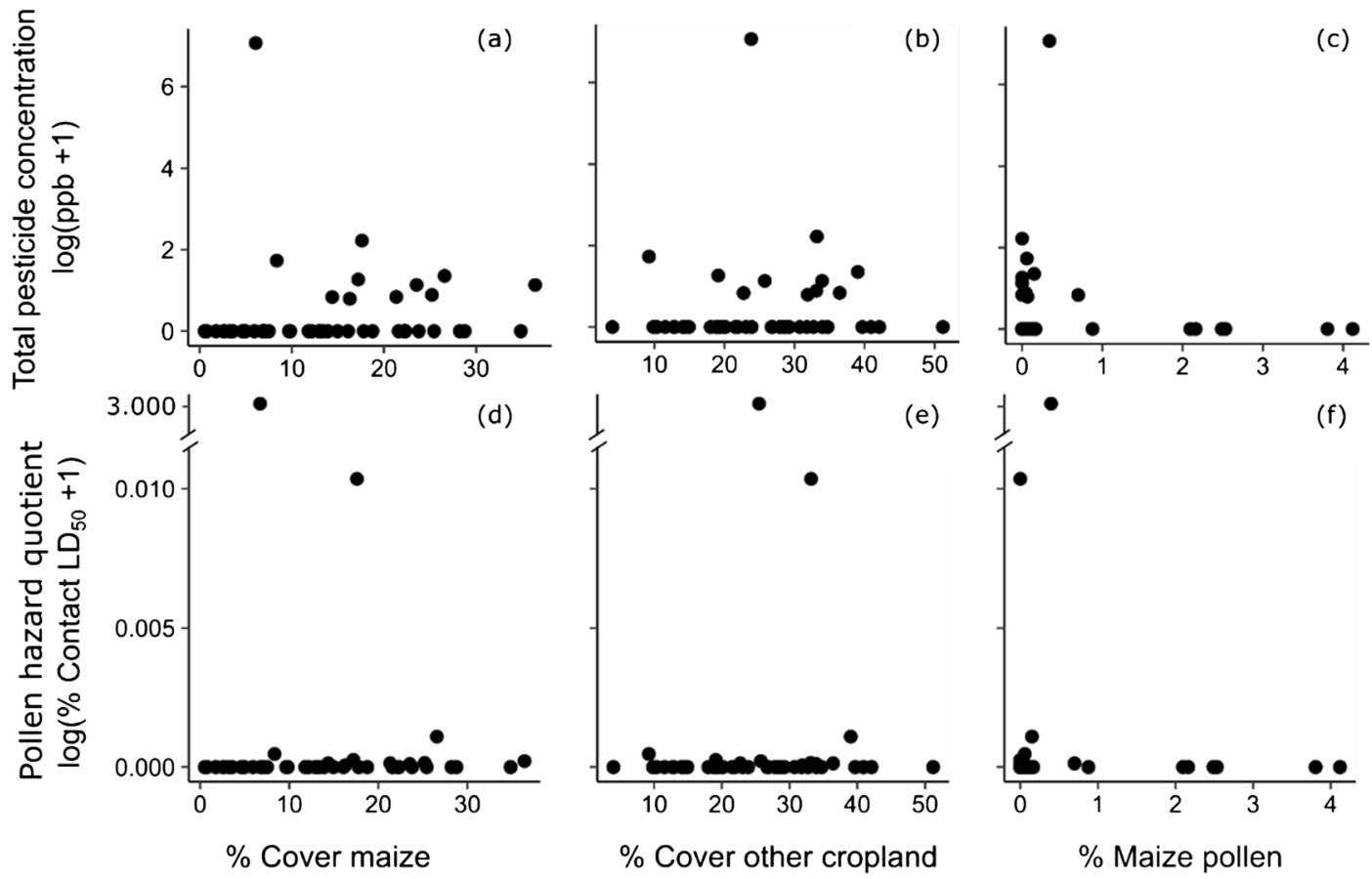

Figure 2. Relationships between total pesticide concentration in bee bread $(\mathbf{a}-\mathbf{c})$ or pollen hazard quotient $(\mathbf{d}-\mathbf{f})$ and percent cover of maize fields within $2 \mathrm{~km}$ of hives, percent cover of other cropland within $2 \mathrm{~km}$ of hives, and percent maize pollen in bee bread. Note the break in the pollen hazard quotient $y$-axis. 


\section{DISCUSSION}

In this study, we assessed spatial and temporal variation in pesticide residues in bee-collected pollen to understand how foraging in and around maize fields may expose bees to pesticides. Contrary to our predictions, neither landscape context nor percent maize pollen was related to pesticide concentration or risk. Furthermore, pesticide risk was low $\left(<1 \%\right.$ contact $\left.\mathrm{LD}_{50}\right)$ in all but one of the pollen samples, and maize pollen was absent in the majority of pollen samples. These results demonstrate that honey bees in our study area typically foraged on alternative pollen sources with low pesticide risk and that collecting low quantities of maize pollen did not increase risk.

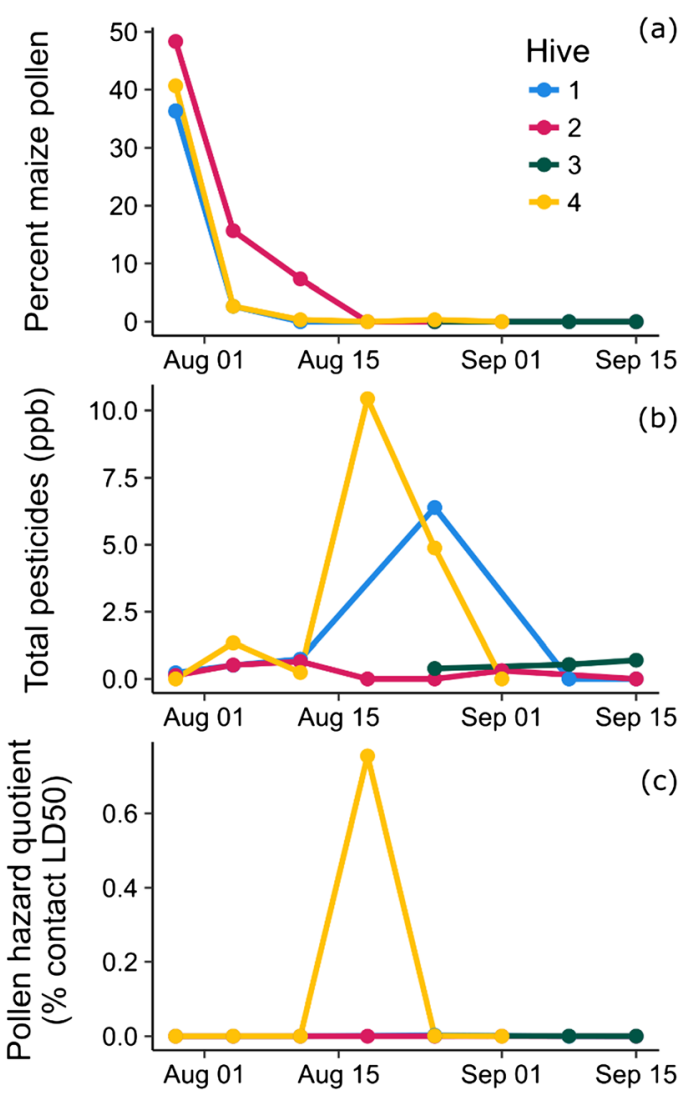

Fig. 3 Percent maize pollen (a), total pesticide concentrations (b), and pollen hazard quotients (c) in 22 pollen-trap samples from four hives. Note that Hive 3 was only sampled on four dates.
Recent studies have shown that neonicotinoids and other pesticides in agricultural landscapes are ubiquitous across space (Krupke et al. 2017) and throughout the growing season (Long and Krupke 2016; Tsvetkov et al. 2017). The agricultural areas surveyed in these previous studies were dominated by a combination of maize and soybeans, which, on average, composed more than $50 \%$ of the landscape surrounding hives (Long and Krupke 2016; Tsvetkov et al. 2017). In contrast to previous studies, we conducted our study in a less intensive and more heterogeneous agricultural system dominated by natural landcover interspersed with cropland. Maize and soybeans, combined, composed on average $18 \%$ of the landscapes surrounding hives; only 1 of the 49 sites was surrounded by more than $50 \%$ soy and maize. Our more heterogeneous study area likely provided bees with accessible, alternative pollen sources, such as other flowering crops and wildflowers. The consistently low maize pollen collection in 2015 suggests that bees may have preferred these resources over maize. Furthermore, the observed low pesticide prevalence and risk suggest that these alternative pollen sources had little or no pesticide contamination. One possible explanation for this low contamination of alternative pollen sources is that, compared to intensive systems, fewer pesticides were entering the environment due to the lower area of cropland treated with neonicotinoids and other pesticides. Additionally, hedgerows and forests in the heterogeneous landscape may have acted as natural windbreaks, substantially reducing drift (Ucar and Hall 2001), and bees may have foraged on wildflowers in areas far from treated fields. It is also possible that growers minimized the volume of neonicotinoids and other pesticides applied to crops, but we lack pesticide application data for the maize fields or other surrounding crops. However, we are confident that the vast majority of maize fields surrounding hives were treated with neonicotinoids, as at least $75 \%$ of maize acres in the USA were treated in 2011 (Douglas and Tooker 2015), and the application rate of neonicotinoids on maize in New York nearly doubled from 2011 (9.5 g/acre/year) to 2014 (17.5 g/acre/year, USDA-NASS 2017). Regardless of the mechanism resulting in low pesticide risk, our results suggest that previous findings of prevalent pesticide exposure and risk during and after 
maize flowering may not be applicable to less intensive agricultural systems.

Hives in the 2016 bee yard collected up to $48 \%$ of their pollen from maize on one sampling date. On this date, pesticide residues were relatively low, no neonicotinoids were detected, and the most common compound was piperonyl butoxide, which is a synergist applied to a number of crops. The absence of neonicotinoids on this date suggests that maize surrounding the 2016 bee yard was not treated with neonicotinoids or that the variety of maize accumulated few neonicotinoid residues in its pollen (Bonmatin et al. 2005; Krupke et al. 2012). Because maize pollen collection was highest on the first day of sampling, we may have missed peak pollen release in the surrounding maize fields. While we may have therefore underestimated total maize pollen collection in this one yard in 2016, our data suggest that additional foraging on maize pollen in this particular field in 2016 may not have increased neonicotinoid exposure. Comparing across years, we found a higher percentage of maize pollen in 2016 samples than 2015 samples. This difference may be a function of the pollen sampling method. Trapped pollen, sampled in 2016, represents a snapshot over 1 to 2 days, allowing us to track fine-scale variation in pollen collection over time. Fresh bee bread, sampled in 2015 , integrates over $\sim 4$ to 5 days of foraging (Anderson et al. 2014), and other pollen collected during this time period could have diluted the percentage of maize pollen in the sample. Any residues on maize pollen were probably also diluted to low or non-detectable levels, and consistently low pesticide levels and maize pollen collection likely led to our finding that these variables were not related in 2015.

While neonicotinoids are some of the most toxic pesticides to bees, we also analyzed a suite of other pesticides that may be present in the landscape (Fernandez-Cornejo et al. 2014). Similar to the results from Indiana (Krupke et al. 2012; Long and Krupke 2016), two of the most prevalent pesticides were the fungicides azoxystrobin and trifloxystrobin. Both of these fungicides are used in seed treatments and are also sprayed on maize during anthesis (Munkvold 2009). Little research has been conducted on synergisms between these two fungicides and neonicotinoids or other insecticides. However, fungicides known to have direct and synergistic effects on bee performance, mainly ergosterol biosynthesis inhibitors, were not prevalent (Pettis et al. 2013; Fernandez-Cornejo et al. 2014; Tsvetkov et al. 2017). Phosmet, detected in one site, had the highest concentration $(1173 \mathrm{ppb})$ and pollen hazard quotient (18.9\% of the contact $\mathrm{LD}_{50}$ ). This pesticide is widely applied to fruit crops at a high application rate compared to other foliar pesticides (Park et al. 2015), and other studies have found phosmet in bee pollen at similar or higher concentrations (Stoner and Eitzer 2013; Sanchez-Bayo and Goka 2014).

There are four caveats to consider when interpreting our results. First, due to limitations of the liquid chromatography-mass spectrometry method, we could not screen for glyphosate, which is applied at relatively high volumes on maize in New York (USDA-NASS 2017). This pesticide is generally considered low risk to bees (but see Balbuena et al. 2015; Motta et al. 2018 regarding sub-lethal effects) and likely would not contribute substantially to our risk results. Second, aside from the small amounts of nectar within bee bread, we did not account for pesticides in nectar. Tsvetkov et al. (2017) found that agrochemicals were approximately three times more prevalent in pollen samples than nectar samples, and average neonicotinoid concentrations were higher in pollen than nectar. While these results suggest that pollen better reflects total pesticide risk, pesticides can be present in nectar of crops and wildflowers in field margins at concentrations that can pose risk to bees (Stoner and Eitzer 2012; Botías et al. 2015). Third, pollen hazard quotients are approximations of pesticide risk and do not take into account sublethal effects from chronic exposure, synergistic interactions within pesticide formulations and between pesticides, and risk posed to larvae, which is the stage that consumes the most bee bread (Aliouane et al. 2009; Gill et al. 2012; Sandrock et al. 2014; Sgolastra et al. 2018). Nonetheless, pollen hazard quotients allow for comparing relative risk in a biologically meaningful way by taking into account pesticide toxicity and exposure (Stoner and Eitzer 2013). Lastly, it is important to note that because our aim was to quantify the risk of pesticides during and after maize flowering, we did not quantify exposure and risk during sowing, which can be high enough 
to lead to acute mortality of bees (Marzaro et al. 2011; Samson-Robert et al. 2017).

Taken together, our study suggests that hives located near maize fields during maize flowering are not necessarily exposed to high concentrations of neonicotinoids and other pesticides, particularly in heterogeneous landscapes. The availability of alternative, uncontaminated pollen sources in heterogeneous landscapes likely helps protect bees from high pesticide risk. Our findings contrast with those from more intensive cropping systems, where honey bees face chronic pesticide exposure (Krupke et al. 2012; Long and Krupke 2016) and where most US maize is produced. Repeating this study over a wider gradient of land-use intensities, or quantifying land use around sites where pesticides in hives have already been measured (e.g., Mullin et al. 2010; Mullen et al. 2017; Tosi et al. 2018), could improve our understanding of how landscape context may mediate the risk posed by pesticides applied to mass-flowering crops.

\section{ACKNOWLEDGEMENTS}

We thank Andy Card, Ashley Fersch, and Nelson Milano with assistance in the field and lab.

\section{AUTHORS CONTRIBUTION}

$\mathrm{SM}, \mathrm{SB}$, and $\mathrm{KB}$ conceived this research and designed the field studies; SB collected the field data; $\mathrm{NB}, \mathrm{KB}$, and MR performed lab analyses; CU analyzed the data; $\mathrm{CU}$ and SM interpreted the data; $\mathrm{CU}$ wrote the first manuscript draft; SM and CU revised the manuscript. All authors read, edited, and approved the final manuscript.Funding information

This study was funded by the USDA (Federal Capacity Fund \#1010568) and the NYS Environmental Protection Fund. Any opinions, findings, and conclusions or recommendations expressed in this material are those of the authors and do not necessarily reflect the views of the funding agencies.

\section{COMPLIANCE WITH ETHICAL STANDARDS}

Conflict of interest The authors declare that they have no conflict of interest.
Faible collecte de pollen de maïs et faible risque de pesticide pour les abeilles mellifères dans des paysages agricoles hétérogènes

Maïs/Zea mays/pesticides/néonicotinoïdes/ pollinisateur/Apis mellifera

Geringe Sammelaktivität in Mais und geringes Pestizidrisiko für Honigbienen in heterogenen Agrarlandschaften.

Mais/Zea mays/Pestizide/Neonicotinoide/Bestäuber/ Apis mellifera

\section{REFERENCES}

Aliouane Y, el Hassani AK, Gary V, Armengaud C, Lambin M, Gauthier M (2009) Subchronic exposure of honeybees to sublethal doses of pesticides: Effects on behavior. Environ. Toxicol. Chem. $28: 113-122$. https://doi. org/10.1897/08-110.1

Anastassiades M, Lehotay SJ, Stajnbaher D, Schenck FJ (2003) Fast and easy multiresidue method employing acetonitrile extraction/partitioning and "dispersive solid-phase extraction" for the determination of pesticide residues in produce. J. AOAC Int. 86:412-431

Anderson KE, Carroll MJ, Sheehan T, Mott BM, Maes P, Corby-Harris V (2014) Hive-stored pollen of honey bees: many lines of evidence are consistent with pollen preservation, not nutrient conversion. Mol. Ecol. $23: 5904-5917$. https://doi.org/10.1111/mec. 12966

Balbuena MS, Tison L, Hahn M-L, Greggers U, Menzel R, Farina WM (2015) Effects of sublethal doses of glyphosate on honeybee navigation. J. Exp. Biol. 218 :27992805. https://doi.org/10.1242/jeb.117291

Bates D, Maechler M, Bolker B, Walker S, Christensen RHB, Singmann H, Dai B, Scheipl F, Grothendieck G, and Green D (2018) The lme4 package. R package version 1.1-18-1

Bonmatin JM, Marchand PA, Charvet R, Moineau I, Bengsch ER, Colin ME (2005) Quantification of imidacloprid uptake in maize crops. J. Agric. Food Chem. $53: 5336-5341$. https://doi.org/10.1021 /jf0479362

Botías C, David A, Horwood J, Abdul-Sada A, Nicholls E, Hill E, Goulson D (2015) Neonicotinoid residues in wildflowers, a potential route of chronic exposure for bees. Environ. Sci. Technol. $49: 12731-12740$. https://doi.org/10.1021/acs.est.5b03459

Couvillon MJ, Schürch R, Ratnieks FLW (2014) Waggle dance distances as integrative indicators of seasonal foraging challenges. PLoS One 9 :e93495. https://doi. org/10.1371/journal.pone.0093495

Cresswell JE (2011) A meta-analysis of experiments testing the effects of a neonicotinoid insecticide (imidacloprid) 
on honey bees. Ecotoxicology 20:149-157. https://doi.org/10.1007/s10646-010-0566-0

Danner N, Härtel S, Steffan-Dewenter I (2014) Maize pollen foraging by honey bees in relation to crop area and landscape context. Basic Appl. Ecol. 15:677-684. https://doi.org/10.1016/j.baae.2014.08.010

Douglas MR, Tooker JF (2015) Large-scale deployment of seed treatments has driven rapid increase in use of neonicotinoid insecticides and preemptive pest management in U.S. field crops. Environ. Sci. Technol. $49: 5088$-5097. https://doi.org/10.1021/es506141g

Fernandez-Cornejo J, Nehring RF, Osteen C, Wechsler S, Martin A, Vialou A (2014) Pesticide use in U.S. agriculture: 21 selected crops, 1960-2008. U.S. Department of Agriculture, Economic Research Service

Frazier M, Mullin C, Frazier J, Ashcraft S (2008) What have pesticides got to do with it? Am. Bee J. 148:521-524

Frazier MT, Mullin CA, Frazier JL, Ashcraft SA, Leslie TW, Mussen EC, Drummond FA (2015) Assessing honey bee (Hymenoptera: Apidae) foraging populations and the potential impact of pesticides on eight U.S. crops. J. Econ. Entomol. 108 :2141-2152. https://doi.org/10.1093/jee/tov195

Gill RJ, Ramos-Rodriguez O, Raine NE (2012) Combined pesticide exposure severely affects individual- and colony-level traits in bees. Nature $491: 105-108$. https://doi.org/10.1038/nature11585

Goulson D, Nicholls E, Botías C, Rotheray EL (2015) Bee declines driven by combined stress from parasites, pesticides, and lack of flowers. Science 347:1255957. https://doi.org/10.1126/science.1255957

Keller I, Fluri P, Imdorf A (2005) Pollen nutrition and colony development in honey bees: part 1 . Bee World $86: 3-10$. https://doi.org/10.1080/0005772 X.2005.11099641

Klungness LM, Peng Y-S (1983) A scanning electron microscopic study of pollen loads collected and stored by honeybees. J. Apic. Res. 22 :264-271. https://doi. org/10.1080/00218839.1983.11100598

Krupke CH, Hunt GJ, Eitzer BD, Andino G, Given K (2012) Multiple routes of pesticide exposure for honey bees living near agricultural fields. PLoS One 7 :e29268. https://doi.org/10.1371/journal. pone. 0029268

Krupke CH, Holland JD, Long EY, Eitzer BD (2017) Planting of neonicotinoid-treated maize poses risks for honey bees and other non-target organisms over a wide area without consistent crop yield benefit. J. Appl. Ecol. 54 :1449-1458. https://doi.org/10.1111 /1365-2664.12924

Lawrence TJ, Culbert EM, Felsot AS, Hebert VR, Sheppard WS (2016) Survey and risk assessment of Apis mellifera (Hymenoptera: Apidae) exposure to neonicotinoid pesticides in urban, rural, and agricultural settings. J. Econ. Entomol. 109:520-528. https://doi.org/10.1093/jee/tov397

Long EY, Krupke CH (2016) Non-cultivated plants present a season-long route of pesticide exposure for honey bees. Nat. Commun. $7: 11629$. https://doi.org/10.1038 /ncomms 11629

Magnusson A, Skaug HJ, Nielsen A, Berg CW, Kristensen $\mathrm{K}$, Maechler $\mathrm{M}$, van Bentham K, Bolker B, Brooks ME (2017) glmmTMB: Generalized linear mixed models using a template model builder. $\mathrm{R}$ package version 0.13

Manning R (2018) Chemical residues in beebread, honey, pollen and wax samples collected from bee hives placed on canola crops in Western Australia. J. Apic. Res. 57:696-708. https://doi.org/10.1080 /00218839.2018.1494889

Marzaro M, Vivan L, Targa A, Mazzon L, Mori N, Greatti M, Toffolo EP, di Bernardo A, Giorio C, Marton D, Tapparo A, Girolami V (2011) Lethal aerial powdering of honey bees with neonicotinoids from fragments of maize seed coat. Bull. Insectology 64 :119-126

McArt SH, Fersch AA, Milano NJ, Truitt LL, Böröczky K (2017) High pesticide risk to honey bees despite low focal crop pollen collection during pollination of a mass blooming crop. Sci. Rep. $7: 46554$. https://doi. org/10.1038/srep46554

Motta EVS, Raymann K, Moran NA (2018) Glyphosate perturbs the gut microbiota of honey bees. Proc. Natl. Acad. Sci. 115 :10305-10310. https://doi.org/10.1073 /pnas. 1803880115

Mullin CA, Frazier M, Frazier JL, Ashcraft S, Simonds R, vanEngelsdorp D, Pettis JS (2010) High levels of miticides and agrochemicals in North American apiaries: implications for honey bee health. PLoS One 5 :e9754. https://doi.org/10.1371/journal. pone. 0009754

Mullen E, Wheeler MK, Mcart S, Cappy P (2017) NYS Beekeeper Tech Team Report. https://pollinator.cals. cornell.edu. Accessed 1 Oct 2018

Munkvold GP (2009) Seed pathology progress in academia and industry. Annu. Rev. Phytopathol. 47:285-311. https://doi.org/10.1146/annurev-phyto-080508081916

Odoux J-F, Feuillet D, Aupinel P, Loublier Y, Tasei J-N, Mateescu C (2012) Territorial biodiversity and consequences on physico-chemical characteristics of pollen collected by honey bee colonies. Apidologie 43:561-575. https://doi.org/10.1007 /s13592-012-0125-1

Park MG, Blitzer EJ, Gibbs J, Losey JE, Danforth BN (2015) Negative effects of pesticides on wild bee communities can be buffered by landscape context. Proc. R. Soc. B 282 :20150299. https://doi.org/10.1098 /rspb.2015.0299

Pettis JS, Lichtenberg EM, Andree M, Stitzinger J, Rose R, vanEngelsdorp D (2013) Crop pollination exposes honey bees to pesticides which alters their susceptibility to the gut pathogen Nosema ceranae. PLoS One 8 :e70182. https://doi.org/10.1371/journal. pone. 0070182

Potts SG, Biesmeijer JC, Kremen C, Neumann P, Schweiger O, Kunin WE (2010) Global pollinator 
declines: trends, impacts and drivers. Trends Ecol. Evol. $25: 345-353$. https://doi.org/10.1016/j. tree.2010.01.007

Prisco GD, Cavaliere V, Annoscia D, Varricchio P, Caprio E, Nazzi F, Gargiulo G, Pennacchio F (2013) Neonicotinoid clothianidin adversely affects insect immunity and promotes replication of a viral pathogen in honey bees. Proc. Natl. Acad. Sci. 110 :18466-18471. https://doi.org/10.1073/pnas.1314923110

R Core Team (2016) R: A language and environment for statistical computing. R Foundation for Statistical Computing, Vienna, Austria. http://www.r-project.org/

Rundlöf M, Andersson GKS, Bommarco R, Fries I, Hederström V, Herbertsson L, Jonsson O, Klatt BK, Pedersen TR, Yourstone J, Smith HG (2015) Seed coating with a neonicotinoid insecticide negatively affects wild bees. Nature $521: 77-80$. https://doi. org/10.1038/nature14420

Samson-Robert O, Labrie G, Chagnon M, Fournier V (2017) Planting of neonicotinoid-coated corn raises honey bee mortality and sets back colony development. PeerJ 5. https://doi.org/10.7717/peerj.3670

Sanchez-Bayo F, Goka K (2014) Pesticide residues and bees - A risk assessment. PLoS One 9 :e94482. https://doi.org/10.1371/journal.pone.0094482

Sandrock C, Tanadini M, Tanadini LG, Fauser-Misslin A, Potts SG, Neumann P (2014) Impact of chronic neonicotinoid exposure on honeybee colony performance and queen supersedure. PLoS One 9 : e103592. https://doi.org/10.1371/journal.pone.0103592

Sgolastra F, Arnan X, Cabbri R, Isani G, Medrzycki P, Teper D, Bosch J (2018) Combined exposure to sublethal concentrations of an insecticide and a fungicide affect feeding, ovary development and longevity in a solitary bee. Proc. R. Soc. B $285: 20180887$. https://doi.org/10.1098/rspb.2018.0887

Simon-Delso N, Amaral-Rogers V, Belzunces LP, Bonmatin JM, Chagnon M, Downs C, Furlan L, Gibbons DW, Giorio C, Girolami V, Goulson D, Kreutzweiser DP, Krupke CH, Liess M, Long E, McField M, Mineau P, Mitchell EAD, Morrissey CA, Noome DA, Pisa L, Settele J, Stark JD, Tapparo A, Van Dyck H, Van Praagh J, Van der Sluijs JP, Whitehorn PR, Wiemers M (2015) Systemic insecticides (neonicotinoids and fipronil): trends, uses, mode of action and metabolites. Environ. Sci. Pollut. Res. 22 :5-34. https://doi.org/10.1007/s11356-014-3470-y

Smart MD, Pettis JS, Euliss N, Spivak MS (2016) Land use in the Northern Great Plains region of the U.S. influences the survival and productivity of honey bee colonies. Agric. Ecosyst. Environ. 230:139-149. https://doi.org/10.1016/j.agee.2016.05.030

Steffan-Dewenter I, Kuhn A (2003) Honeybee foraging in differentially structured landscapes. Proc. R. Soc. Lond. B Biol. Sci. 270:569-575. https://doi. org/10.1098/rspb.2002.2292

Stoner KA, Eitzer BD (2012) Movement of soil-applied imidacloprid and thiamethoxam into nectar and pollen of squash (Cucurbita pepo). PLoS One 7 :e39114. https://doi.org/10.1371/journal.pone.0039114
Stoner KA, Eitzer BD (2013) Using a hazard quotient to evaluate pesticide residues detected in pollen trapped from honey bees (Apis mellifera) in Connecticut. PLoS One 8 :e77550. https://doi.org/10.1371/journal. pone. 0077550

Tomlin CD (2013) The pesticide manual: A world compendium (16th edition). British Crop Production Council

Tosi S, Costa C, Vesco U, Quaglia G, Guido G (2018) A 3year survey of Italian honey bee-collected pollen reveals widespread contamination by agricultural pesticides. Sci. Total Environ. $615: 208-218$. https://doi. org/10.1016/j.scitotenv.2017.09.226

Tsvetkov N, Samson-Robert O, Sood K, Patel HS, Malena DA, Gajiwala PH, Maciukiewicz P, Fournier V, Zayed A (2017) Chronic exposure to neonicotinoids reduces honey bee health near corn crops. Science 356 :13951397. https://doi.org/10.1126/science.aam 7470

Ucar T, Hall FR (2001) Windbreaks as a pesticide drift mitigation strategy: a review. Pest Manag. Sci. 57 :663-675. https://doi.org/10.1002/ps.341

USDA-NASS Cropland Data Layer (2014) Published cropspecific data layer. https://nassgeodata.gmu. edu/CropScape. Accessed 1 Sept 2018

USDA-NASS (2017) USDA-National Agricultural Statistics Service Quick Stats. https://quickstats.nass.usda. gov. Accessed 15 Jan 2019

Visscher PK, Seeley TD (1982) Foraging strategy of honeybee colonies in a temperate deciduous forest. Ecology $63: 1790-1801$. https://doi.org/10.2307/1940121

Williams GR, Troxler A, Retschnig G, Roth K, Yañez O, Shutler D, Neumann P, Gauthier L (2015) Neonicotinoid pesticides severely affect honey bee queens. Sci. Rep. 5:14621. https://doi.org/10.1038 /srep14621

Woodcock BA, Bullock JM, Shore RF, Heard MS, Pereira MG, Redhead J, Ridding L, Dean H, Sleep D, Henrys P, Peyton J, Hulmes S, Hulmes L, Sárospataki M, Saure C, Edwards M, Genersch E, Knäbe S, Pywell RF (2017) Country-specific effects of neonicotinoid pesticides on honey bees and wild bees. Science $356: 1393-1395$. https://doi.org/10.1126/science. aaa 1190

Wu JY, Anelli CM, Sheppard WS (2011) Sub-lethal effects of pesticide residues in brood comb on worker honey bee (Apis mellifera) development and longevity. PLoS One $6:$ e14720. https://doi.org/10.1371/journal. pone. 0014720

Wu JY, Smart MD, Anelli CM, Sheppard WS (2012) Honey bees (Apis mellifera) reared in brood combs containing high levels of pesticide residues exhibit increased susceptibility to Nosema (Microsporidia) infection. J. Invertebr. Pathol. $109: 326-329$. https://doi. org/10.1016/j.jip.2012.01.005

Publisher's note Springer Nature remains neutral with regard to jurisdictional claims in published maps and institutional affiliations. 